\title{
METHODOLOGY FOR MEASURING THE SHEAR STRESS OF PLASTERBOARDS
}

\author{
Ondřej Zobal ${ }^{a, b, *}$, Robert JÁrA $^{a, b}$, MARTin HAtAJ $^{a, b}$ \\ ${ }^{a}$ Czech Technical University in Prague, University Centre for Energy Efficient Buildings, Třinecká 1024, \\ 27343 Buštěhrad, Czech Republic \\ ${ }^{b}$ Czech Technical University in Prague, Faculty of Civil Engineering, Thákurova 7, 16629 Prague 6, Czech \\ Republic \\ * corresponding author: ondrej.zobal@fsv.cvut.cz
}

\begin{abstract}
Plasterboards have to meet many requirements for certification. The mechanical properties of itself plasterboard are one of them. The important mechanical property of the plasterboard is the shear strength perpendicular to the plane of the board. The European Standard refers to performing the relevant test for the procedure set out in the wood standard EN 789. But is this methodology for plasterboard the most suitable? This paper compares this recommended method with the alternative method according to the American Standard ASTM D5379 with indicating the results of a specific measurement.
\end{abstract}

KEYWORDS: Plasterboard, shear strength perpendicular to the plane of the board, EN 789, ASTM D5379.

\section{INTRODUCTION}

The plasterboard is pressed gypsum mass between two paper cartons for dry construction. This board can be used for reconstructions and new buildings for the construction of partitions, floors and ceilings. The plasterboard can protect against noise, moisture and fire [1. Marking, definition of properties and test methods for gypsum boards are prescribed standard EN $520+$ A1 from the 2010 which, moreover, unifies requirements and designations throughout Europe. Essential requirements include the declared tensile strength in bending and sag, shear strength, compressive strength, hardness and minimum required values of modulus of elasticity for individual stresses [1 5 . All required mechanical properties for certification are given in Tab. 1. Standard EN $520+$ A1 defines 8 types of plasterboard:

(1.) type A - gypsum plasterboard,

(2.) type $\mathrm{H}$ - plasterboard with reduced water absorption rate,

(3.) type E - gypsum sheathing board,

(4.) type F - gypsum plasterboard with improved core adhesion at high temperature,

(5.) type $\mathrm{P}$ - plasterboard,

(6.) type D - gypsum plasterboard with controlled density,

(7.) type R - gypsum plasterboard with enhanced strength,

(8.) type I - gypsum plasterboard with enhanced surface hardness.
This paper addresses the determination of shear strength perpendicular to the plane of the board. European standards DIN 18180 from 2014 and EAD 07001-01-0504 from 2016 refer to the shear strength test perpendicular to the plane of the board to EN 789, which is, however, focused to wood-based boards [6] 8. It has been found that the shear strength test perpendicular to the plane of the board according to EN 789 is performed very rare in test institutes in the Czech Republic (two places) and only one test facility has been discovered on the university campus. For these two reasons, we decided to try a different and more accessible way of testing. The US standard ASTM D5379 for testing the shear properties of composite materials was finally chosen as an alternative shear strength test perpendicular to the plane of the board [9]. The paper compares results and measurement procedures these two standards.

\section{Methodology of MeAsurement}

\subsection{STANDARD EN 789}

The test specimen had the dimensions of $450 \times 900 \times$ thickness of board [mm] and each board was cut one in the longitudinal direction and one in the transverse direction. We needed wooden or steel guide parts for fixing the test specimen. The guide parts had to meet the criteria (minimum dimensions, same humidity as the test specimen, minimum strength and rigidity). The connection of the guide parts and test specimen had to be done with a suitable adhesive. The static scheme is shown in Fig. 1 and Fig. 2 shows a load arrangement for a shear strength test perpendicular to the plane of the board. 


\begin{tabular}{|c|c|c|c|c|c|}
\hline Mechanical properties & $\begin{array}{l}\text { Designa- } \\
\text { tion }\end{array}$ & $\begin{array}{l}\text { Dir. } \\
{\left[{ }^{\circ}\right]}\end{array}$ & $\begin{array}{l}\text { Nr. of } \\
\text { tests }\end{array}$ & $\begin{array}{c}\text { Spec. } \\
\text { width } \\
{[\mathrm{mm}]}\end{array}$ & $\begin{array}{c}\text { Spec. } \\
\text { length } \\
{[\mathrm{mm}]}\end{array}$ \\
\hline $\begin{array}{l}\text { Bending strength perpendicular to the plane of the } \\
\text { board - in the longitudinal direction }\end{array}$ & $\mathrm{f}_{\mathrm{m}, 0, \mathrm{k}}$ & 0 & 3 & 400 & 300 \\
\hline $\begin{array}{l}\text { Bending strength perpendicular to the plane of the } \\
\text { board - in the transverse direction }\end{array}$ & $\mathrm{f}_{\mathrm{m}, 90, \mathrm{k}}$ & 90 & 3 & 400 & 300 \\
\hline $\begin{array}{l}\text { Modulus of elasticity in bending perpendicular to } \\
\text { the plane of the board - longitudinally }\end{array}$ & $\mathrm{E}_{\mathrm{m}, 0, \text { mean }}$ & 0 & - & - & - \\
\hline $\begin{array}{l}\text { Modulus of elasticity in bending perpendicular to } \\
\text { the plane of the board - transversely }\end{array}$ & $\mathrm{E}_{\mathrm{m}, 90, \text { mean }}$ & 90 & - & - & - \\
\hline $\begin{array}{l}\text { Shear strength in the plane of the board - longitu- } \\
\text { dinally }\end{array}$ & $\mathrm{f}_{\mathrm{v}, 0, \mathrm{k}}$ & 0 & 3 & 500 & 600 \\
\hline $\begin{array}{l}\text { Shear strength in the plane of the board - trans- } \\
\text { versely }\end{array}$ & $\mathrm{f}_{\mathrm{v}, 90, \mathrm{k}}$ & 90 & 3 & 500 & 600 \\
\hline $\begin{array}{l}\text { Modulus of elasticity in shear in the plane of the } \\
\text { board - longitudinally }\end{array}$ & $\mathrm{G}_{\mathrm{v}, 0, \text { mean }}$ & 0 & - & - & - \\
\hline $\begin{array}{l}\text { Modulus of elasticity in shear in the plane of the } \\
\text { board - transversely }\end{array}$ & $\mathrm{G}_{\mathrm{v}, 90, \text { mean }}$ & 90 & - & - & - \\
\hline $\begin{array}{l}\text { Compressive strength perpendicular to the plane of } \\
\text { the board - longitudinally }\end{array}$ & $\mathrm{f}_{\mathrm{c}, 0, \mathrm{k}}$ & 0 & 3 & 400 & 400 \\
\hline $\begin{array}{l}\text { Compressive strength perpendicular to the plane of } \\
\text { the board - transversely }\end{array}$ & $\mathrm{f}_{\mathrm{c}, 90, \mathrm{k}}$ & 90 & 3 & 400 & 400 \\
\hline $\begin{array}{l}\text { Bending strength in the plane of the board - in the } \\
\text { longitudinal direction }\end{array}$ & $\mathrm{f}_{\mathrm{m}, 0, \mathrm{k}}$ & 0 & 3 & 400 & 300 \\
\hline $\begin{array}{l}\text { Bending strength in the plane of the board - in the } \\
\text { transverse direction }\end{array}$ & $\mathrm{f}_{\mathrm{m}, 90, \mathrm{k}}$ & 90 & 3 & 400 & 300 \\
\hline $\begin{array}{l}\text { Modulus of elasticity in bending in the plane of the } \\
\text { board - longitudinally }\end{array}$ & $\mathrm{E}_{\mathrm{m}, 0, \text { mean }}$ & 0 & - & 6 & 6 \\
\hline $\begin{array}{l}\text { Modulus of elasticity in bending in the plane of the } \\
\text { board - transversely }\end{array}$ & $\mathrm{E}_{\mathrm{m}, 90, \text { mean }}$ & 90 & - & - & - \\
\hline $\begin{array}{l}\text { Compressive strength in the plane of the board - } \\
\text { longitudinally }\end{array}$ & $\mathrm{f}_{\mathrm{c}, 0, \mathrm{k}}$ & 0 & 3 & 400 & 400 \\
\hline $\begin{array}{l}\text { Compressive strength in the plane of the board - } \\
\text { transversely }\end{array}$ & $\mathrm{f}_{\mathrm{c}, 90, \mathrm{k}}$ & 90 & 3 & 400 & 400 \\
\hline $\begin{array}{l}\text { Modulus of elasticity in compressive in the plane of } \\
\text { the board - longitudinally }\end{array}$ & $\mathrm{E}_{\mathrm{c}, 0, \text { mean }}$ & 0 & - & - & - \\
\hline $\begin{array}{l}\text { Modulus of elasticity in compressive in the plane of } \\
\text { the board - transversely }\end{array}$ & $\mathrm{E}_{\mathrm{c}, 90, \text { mean }}$ & 90 & - & - & - \\
\hline $\begin{array}{l}\text { Tensile strength in the plane of the board - longitu- } \\
\text { dinally }\end{array}$ & $\mathrm{f}_{\mathrm{t}, 0, \mathrm{k}}$ & 0 & 3 & 50 & 350 \\
\hline $\begin{array}{l}\text { Tensile strength in the plane of the board - trans- } \\
\text { versely }\end{array}$ & $\mathrm{f}_{\mathrm{t}, 90, \mathrm{k}}$ & 90 & 3 & 50 & 350 \\
\hline $\begin{array}{l}\text { Modulus of elasticity in tensile in the plane of the } \\
\text { board - longitudinally }\end{array}$ & $\mathrm{E}_{\mathrm{t}, 0, \text { mean }}$ & 0 & - & - & - \\
\hline $\begin{array}{l}\text { Modulus of elasticity in tensile in the plane of the } \\
\text { board - transversely }\end{array}$ & $\mathrm{E}_{\mathrm{t}, 90, \text { mean }}$ & 90 & - & - & - \\
\hline Shear strength - core + carton & $\mathrm{f}_{\text {shear, max }}$ & - & 6 & 600 & 170 \\
\hline Determination of surface hardness of the board & - & - & 6 & 300 & 400 \\
\hline
\end{tabular}

TABLE 1. Comparison of test of the shear strength perpendicular to the plane of the board according to the standards EN 789 and ASTM D5379. 

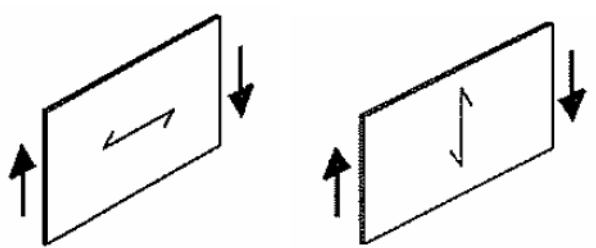

FiguRE 1. Static scheme of the test of shear strength perpendicular to the plane of the board 6 .

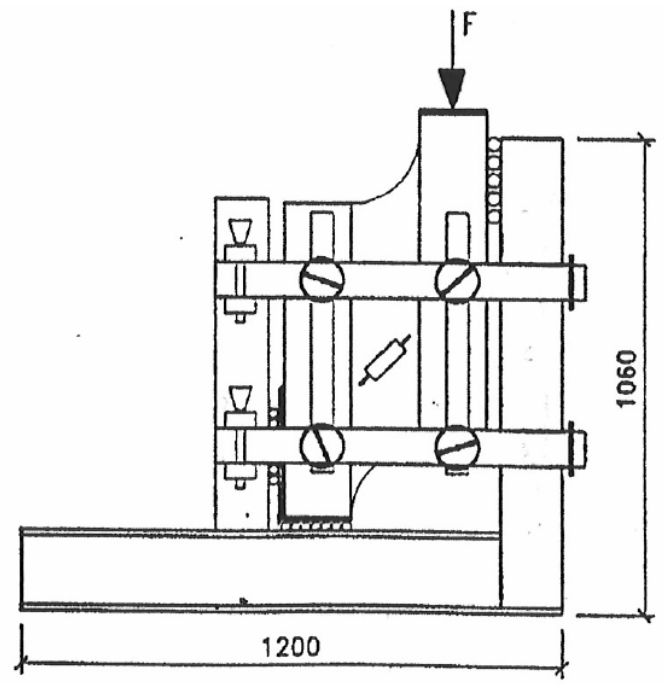

Figure 2. The load arrangement for a shear strength test perpendicular to the plane of the board according standard EN 789 (dimensions are in $\mathrm{mm}$ ) 8].

All test specimens were loaded with incremental strain at a constant rate of $2 \mathrm{~mm} / \mathrm{min}$ until failure. The shear strength perpendicular to the plane of the board was given by the following Equation 1.

$$
f_{v}=\frac{F_{\max }}{l . t},
$$

where $f_{v}$ is shear strength perpendicular to the plane of the plate [MPa], $F_{\max }$ is the maximum load at failure $[\mathrm{N}], l$ is the length of the test specimen measured along the centerline of the shear area $[\mathrm{mm}], t$ is the average thickness of the test specimen measured at two points along centerline the shear area $[\mathrm{mm}]$.

\subsection{STANDARD ASTM D5379}

The test specimen had the dimensions of $19.1 \times 76.2 \times$ thickness of board [mm] and it was necessary to cut the specimens in the longitudinal and transverse directions from each board. No guide parts were needed to fasten the test specimen. Loading scheme was the same as for the standard EN 789 (Fig. 1). The loading arrangement with the shape and size of the test specimen for the shear strength test perpendicular to the plane of the board according to ASTM D5379 is shown in Fig. 3 The strength evaluation was performed according to Eq. 1 .

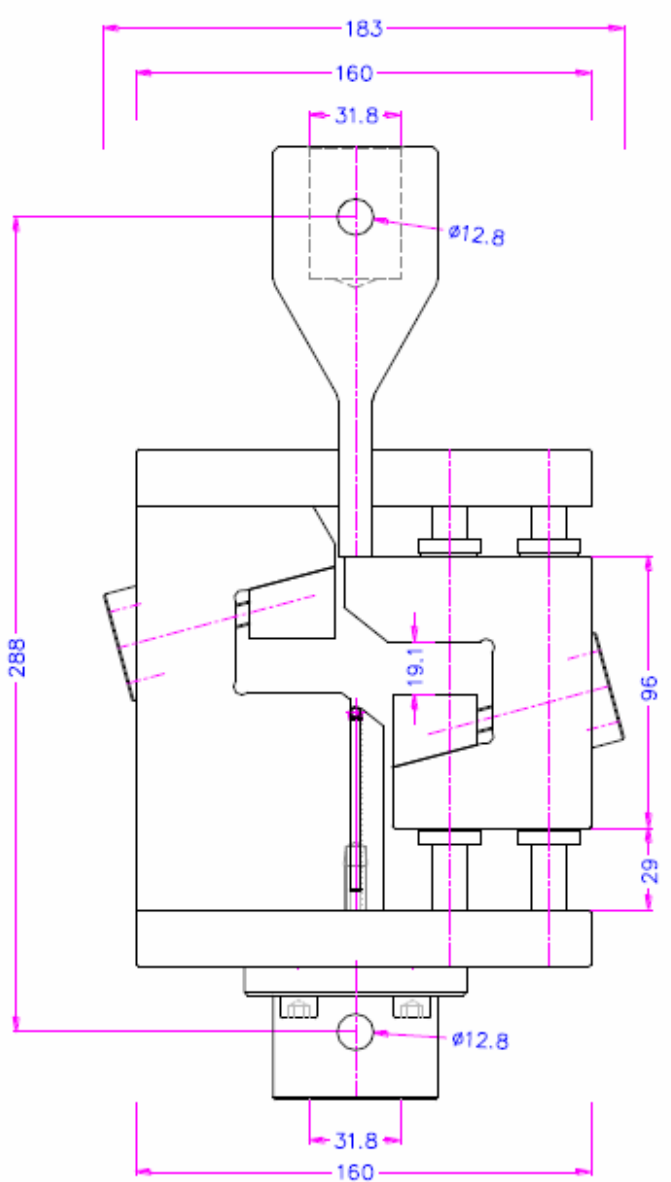

Figure 3. The load arrangement for a shear strength test perpendicular to the plane of the board with test specimen according standard ASTM D5379 (dimensions are in $\mathrm{mm}$ ) [10].

\section{Results of MEASUREMENT}

The number of test specimens according EN 789 was 6 pieces (3 different boards, $1 \times$ longitudinal and $1 \times$ transverse direction from each board). The number of test specimens according ASTM D5379 was 30 pieces ( 3 different boards, $5 \times$ longitudinal and $5 \times$ transverse direction from each board). Fig. 4 shows a shear strength test perpendicular to the plane of the board according to ASTM D5379.

The characteristic value of shear strength according to EN 789 was in the longitudinal and transverse direction same 2.8 MPa. The shear strength according to ASTM D5379 had characteristic value in the longitudinal direction of $3.1 \mathrm{MPa}$ and in the transverse direction of 2.7 MPa. The differences of values of shear strength with the standard deviation results under $10 \%$ were minimal. 


\begin{tabular}{cccc}
\hline Standard & $\begin{array}{c}\text { Size of the test } \\
\text { specimen }[\mathrm{mm}]\end{array}$ & $\begin{array}{c}\text { Difference of } \\
\text { characteristic values }[\%]\end{array}$ & Note \\
\hline EN 789 & $600 \times 900 \times$ thickness & $\mathrm{f}_{\mathrm{v}, 0, \mathrm{k}}=10.7$ & $\begin{array}{c}\text { problem with fastening test } \\
\text { specimen }\end{array}$ \\
\cline { 1 - 2 } & $19.1 \times 76.2 \times$ thickness & $\mathrm{f}_{\mathrm{v}, 90, \mathrm{k}}=3.5$ & - \\
\hline
\end{tabular}

TABlE 2. Comparison of test of the shear strength perpendicular to the plane of the board according to the standards EN 789 and ASTM D5379.

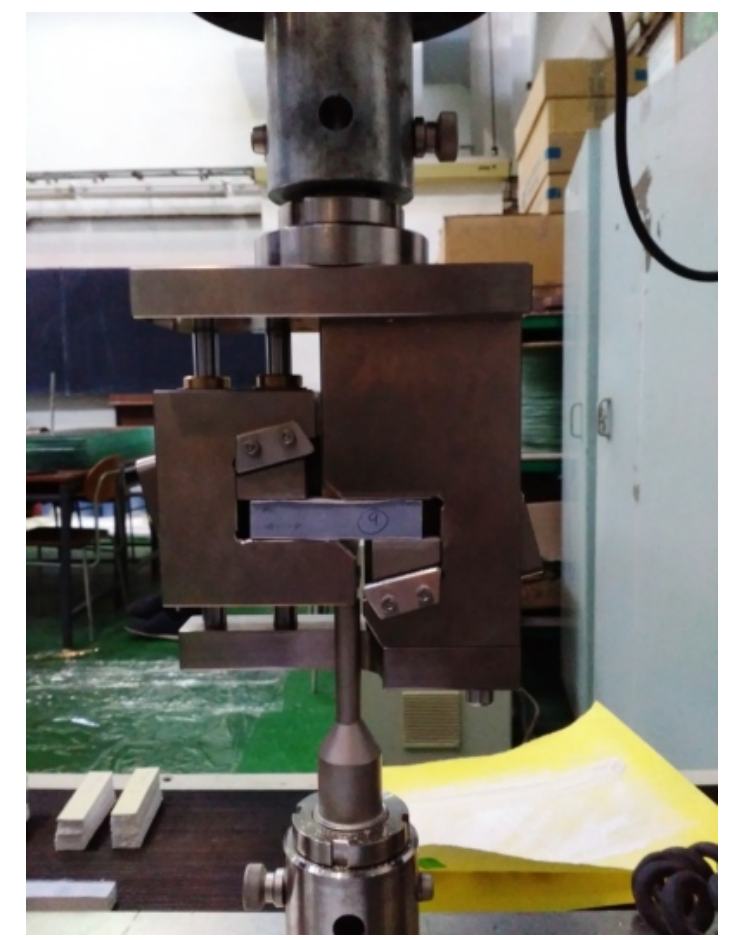

Figure 4. Test of shear strength perpendicular to the plate plane according to ASTM D5379.

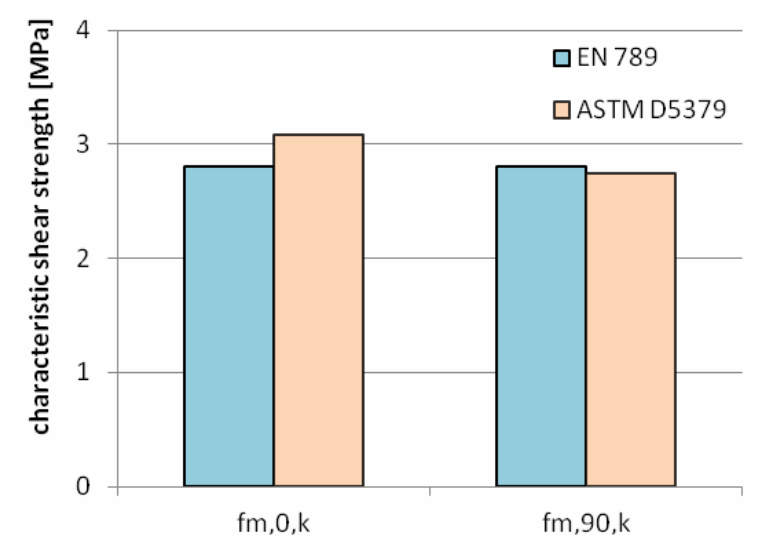

FIGURE 5. Characteristic values of shear strength perpendicular to the plane of the plate according to the standards EN 789 and ASTM D5379.

\section{Conclusions}

As is shown in Tab. 2, values of shear strength measurements according to EN 789 and ASTM D5379 are very similar. The EN 789 standard is determined primarily for wood-based materials. The test specimens according to EN 789 are very large and there is a problem with their attachment and ensuring stability during the test.

A numerical model will be created to comparing the results according to EN 789 and ASTM D5379 on the basis of the obtained test parameters in the next phase of our work.

\section{ACKNOWLEDGEMENTS}

This work has been supported by the Faculty of Civil Engineering, Czech Technical University in Prague (SGS project No. SGS16/201/OHK1/3T/11) and by the Ministry of Education, Youth and Sports within National Sustainability Programme I, project No. LO1605.

\section{REFERENCES}

[1] Gypsum unique properties in buildings. http: //www . eurogypsum .org/about-gypsum/properties/.

[2] Plasterboards according to european standards. http://imaterialy.dumabyt.cz/rubriky/ drevene-a-montovane-konstrukce/ sadrokartonove-desky-podle-evropskych-norem_ 101335.html.

[3] CNI. Gypsum plasterboards - Definitions, requirements and test methods. First printing. Prague, 2010.

[4] D. Supik. Analysis of selected mechanical properties of construction materials for wood building. thesis statement. Mendel University in Brno, 2009.

[5] C. Petrone, G. Magliulo, G. Manfredi. Mechanical properties of plasterboards: experimental tests and statistical analysis. Journal of Materials in Civil Engineering 28(11):04016129, 2016.

[6] DIN. Gypsum plasterboards - Definitions, requirements and test methods. First printing. Berlin, 2014.

[7] EAD. Gypsum plasterboard for load-bearing applications. First printing. EOTA, 2016.

[8] CNI. Timber structures - Test methods Determination of mechanical properties of wood based panels. First printing. Prague, 2005.

[9] D. ASTM. 5379:"standard test method for shear properties of composite materials by the v-notched beam method". Annual Book of ASTM Standards 100:235-47, 2012. 
[10] Shear test fixture astm d5379.

http://www.grip.de/pdf/THS600_Datasheet.pdf 